\title{
Evaluation of the occurrence of anxiety in pregnant women with regard to environmental conditions
}

\author{
DOROTA BRANECKA-WOŹNIAK ${ }^{1, B, E}$, BEATA KARAKIEWICZ2, A, ANDRZEJ TORBÈ ${ }^{3, D}$, \\ PRZEMYSŁAW CIEPIELA ${ }^{1, B, F}$, BOŻENA MROCZEK ${ }^{4,}$, MARTA STANISZ $^{1, \text { B }}$, \\ ANNA JURCZAK ${ }^{5, B, F}$, RAFAŁ KURZAWA ${ }^{1, A, C}$ \\ ${ }^{1}$ Department of Gynecology and Reproductive Health Pomeranian Medical University, Szczecin, Poland \\ ${ }^{2}$ Department of Public Health, Pomeranian Medical University, Szczecin, Poland \\ ${ }^{3}$ Clinic of Obstetrics and Gynecology, Independent Public Clinical Hospital No. 2 Pomeranian Medical University, \\ Szczecin, Poland \\ ${ }^{4}$ Department of Humanities in Medicine, Pomeranian Medical University, Szczecin, Poland \\ ${ }^{5}$ Department of Clinical Nursing, Pomeranian Medical University, Szczecin, Poland
}

A - Study Design, B - Data Collection, C - Statistical Analysis, D - Data Interpretation, E - Manuscript Preparation, F - Literature Search, G - Funds Collection

Summary Background. A mother's health, her family relations and social-economic conditions are factors which determine the course of pregnancy, childbirth and puerperal period.

Objectives. The main aim of the study was analysis and evaluation of anxiety levels in particular trimesters of pregnancy with regard to selected environmental factors.

Material and methods. The study included 250 pregnant women with a median age of 29 (range 19-47 years) in the territory of Western Poland. It was a prospective longitudinal study, and it was carried out in three stages. All three stages of the study were completed by 181 pregnant women. The study applied a diagnostic poll method - State-Trait Anxiety Inventory (STAI), as well as the authors' questionnaire in the form of a family interview for those pregnant.

Results. A highly significant $(p<0.001)$ positive correlation between trait anxiety and the intensification of state anxiety during particular trimesters of pregnancy was noted. Those women who did not receive family support during pregnancy declared worse housing conditions and a dire financial situation, as well as experiencing stress, but also suffered from state anxiety at a significantly higher level $(p<0.001)$ during all three trimesters of pregnancy.

Conclusions. Lack of support from family resulted in experiencing very intense anxiety by the women researched in each trimester. Financial issues and the housing situation, as well as stress factors, brought about an escalation of anxiety in pregnant women. Key words: pregnancy, environment, anxiety, State-Trait Anxiety Inventory (STAI).

Branecka-Woźniak D, Karakiewicz B, Torbè A, Ciepiela P, Mroczek B, Stanisz M, Jurczak A, Kurzawa R. Evaluation of the occurrence of anxiety in pregnant women with regard to environmental conditions. Fam Med Prim Care Rev 2018; 20(4): 320-326, doi: https://doi. org/10.5114/fmpcr.2018.79341.

\section{Background}

For a woman, pregnancy is a period of multiple changes in their bio-psychosocial functioning, and every life event which brings about a massive change, either positive or negative, may cause stress [1-3]. A new situation results in an increase in totally new emotions and needs, and pregnancy is not emotionally indifferent even if it is expected and planned [4]. A woman whose financial situation is deficient experiences even more negative feelings [5]. Incommunicative women who have problems in building relations with others and are incapable of asking for support are also prone to anxiety [6]. Social support is believed to have a particular impact on the maintenance of human health. People with a family, who have many friends and enjoy better health cope better with difficult and stressful situations. Social support is extremely important in the process of daily struggles with stress. Its positive influence was also proven in fighting post-traumatic and work-related stress, mental crisis, as well as fighting addictions and somatic diseases. Emotional support is also crucial during pregnancy and in childbirth [7]. The support received by a woman during pregnancy can significantly help in preventing postpartum depression. The causes of puerperal depression are complex. The reasons can be biological, biochemical, psychological and social, and more often it is a result of all of the above variables [8]. Usually, the fear experienced during pregnancy has its consequences during the postnatal period, influencing the quality of life of the mother and reducing the satisfaction of life. The comfort of life is linked to the social support received [9]. Psychosocial stress, to which pregnant women are exposed, poses a risk of increased susceptibility to stress in the child in postnatal life. This is followed by an increased level of cortisol, which increases the intake of highcalorie foods, leads to neurobiological adaptation and a compulsive nature of overeating.

Chronic tension causes an increase in the levels of "stress" hormones that penetrate the fetal bloodstream, causing abnormalities in the formulation of nutritional behavior. A consequence is the risk of developing overweight and obesity in children of mothers who have had chronic stress during pregnancy [10-13]. When anxiety occurs during the perinatal period, it may result in severe pregnancy or childbirth disorders or emotional disturbances after giving birth [14]. Unsolved emotional problems during this time may have a long-lasting negative influence on the family, the baby and the woman herself [15-17]. 
Reducing anxiety levels during pregnancy and childbirth in many cases undoubtedly contributes to a lesser number of pregnancy pathologies, and it also influences normality in childbirth, improves the postnatal state of newborns and helps decrease the risk of the "baby blues" or postnatal depression [18-20]. Anxiety is a natural part of our lives. It is induced by situational factors, most frequently connected with threat. These are not just real, existing threats, but also those that are expected or even imagined [21]. Their intensity changes due to changes in the situation. [22]. A mother's health, her physical and mental disposition, lifestyle, family relationships and social-economic conditions determine the course of pregnancy and childbirth [23]. Irregularities in these spheres may predispose the mother to pathologies during pregnancy and childbirth. However, the area of difficulty which is remarkably gaining attention is the woman's mental state related to the trimester of pregnancy [24]. A high level of anxiety during pregnancy may have a significant impact on health and the development of the relation between a mother and her child. This also concerns the health of the family, both mental and physical. In particular, the need to accept the new situation, often necessitating the introduction of many significant changes in life, introduces women into a state which can contribute to the disclosure or worsening of pre-existing anxiety disorders.

\section{Objectives}

The main aim of the study was analysis and evaluation of anxiety levels in particular trimesters of pregnancy concerning selected environmental factors.

\section{Material and methods}

The study was conducted with the consent of the Bioethical Commission of the Pomeranian Medical University in Szczecin (No KB-0012/150/12). The study included 181 women (median age 29 , range 19-47 years) in their first trimester of pregnancy. All patients accomplished all three stages of the study (Table 1 ).

\begin{tabular}{|l|l|l|l|}
\hline \multicolumn{4}{|l}{ Table 1. Characteristics of the examined group } \\
\hline Characteristics of the group & $n$ & $\%$ \\
\hline \multirow{4}{*}{ Age } & $19-28$ years old & 79 & 43.65 \\
\cline { 2 - 4 } & $29-35$ years old & 83 & 45.86 \\
\cline { 2 - 4 } & $36-44$ years old & 18 & 9.94 \\
\cline { 2 - 4 } & $>45$ years old & 1 & 0.55 \\
\hline Marital status & married & 103 & 56.90 \\
\cline { 2 - 4 } & single & 34 & 18.78 \\
\cline { 2 - 4 } & free status & 12 & 6.62 \\
\cline { 2 - 4 } & concubinage & 32 & 17.70 \\
\hline Education & higher education & 85 & 46.97 \\
\cline { 2 - 4 } & bachelor's degree & 19 & 10.49 \\
\cline { 2 - 4 } & secondary education & 50 & 27.63 \\
\cline { 2 - 4 } & vocational education & 18 & 9.94 \\
\cline { 2 - 4 } & basic education & 9 & 4.97 \\
\hline \multirow{4}{*}{$\begin{array}{l}\text { Professional } \\
\text { activity }\end{array}$} & yes & 139 & 76.80 \\
\cline { 2 - 4 } & no & 37 & 20.44 \\
\cline { 2 - 4 } & during studies & 5 & 2.76 \\
\hline
\end{tabular}

The study was prospectively longitudinal and was conducted in three stages. During subsequent trimesters of pregnancy, those pregnant received questionnaires to fill in at an appointment, according to the current stage of their pregnancy. The criteria of inclusion into the study group were: being at least 18 years old, presenting at an obstetric-gynecological surgery clinic during the first trimester of pregnancy $\left(13^{\text {th }}-15^{\text {th }}\right.$ week of pregnancy), during the second trimester $\left(27^{\text {th }}-29^{\text {th }}\right.$ week of pregnancy) and the third trimester (completed $37^{\text {th }}$ week of pregnancy). For the study, we applied the use of a standardized research tool: the Spielberger, Gorsucha and Lushene State-Trait Anxiety Inventory (STAI), as well as the authors' own questionnaire in the form of a family interview for those pregnant. The STAI questionnaire includes two independent segments, each consisting of 20 statements (X-1, X-2) with 4 options to choose from: definitely not, probably no, probably yes, definitely yes. The level of anxiety is expressed by the number of points obtained by summing up the points received in each response. Point values for each part of the questionnaire were from 20 to 80 points. High point values mean higher levels of anxiety. The calculation is made using a key. Each scale is an independent measurement tool and does not have one universal numerical measure. The first part of the STAI (X-1) is a very sensitive tool which enables one to trace anxiety dynamics even at short time intervals, allowing one to examine anxiety as current emotional state. The second part of the STAI (X-2) enables one to examine anxiety understood as a permanent personality trait. The family interview questionnaire for those pregnant is a self-composed tool made up of 18 questions concerning: socio-demographic issues, such as age, place of living, marital status and occupation, information about work and risks in the workplace, preferred forms of relaxation, financial and housing situation, type of support. The respondents completed the STAI X-1 and STAI $\mathrm{X}-2$ questionnaires, along with our own family interview questionnaire, during the first trimester; the STAI X-1 questionnaire during the second trimester; and the STAI X-1 questionnaire with our own family interview questionnaire during the third trimester.

\section{Statistical analysis}

The obtained results were statistically analyzed with PQStat ver. 1.4.2.324 software. The following tests were applied: correlations between the scales were analyzed with two-way tables and $\mathrm{chi}^{2}$ test; STAI results, depending on groups in respect to the given answers, were compared with nonparametric tests: U Mann-Whitney and Kruskal-Wallis (in the case when those researched were divided into more than two groups); the relationship between anxiety scales was analyzed with the Spearman rank correlation. The $p$-value $<0.05$ was considered significant.

\section{Results}

The obtained results included environmental and social variables of the examined group (Table 2). Most of the surveyed women indicated that they were exposed to stress factors during pregnancy. They also declared financial issues as the main stress type. A majority of the examined group could count on the support of family and other people during pregnancy.

Trait anxiety occurred at high levels in the first trimester of pregnancy in $54.7 \%$ of women, and in the third trimester, in $59.7 \%$ (Table 3). A highly significant change was noted in state anxiety results in the subsequent trimesters, namely, a decrease in anxiety levels during the second trimester in comparison with the first, and another increase during the last trimester (Table 3, 4).

A highly significant $(p<0.001)$ positive correlation between trait anxiety and the escalation of state anxiety in particular trimesters of pregnancy in those researched was noted. Women who experienced trait anxiety were characterized by a greater intensity of state anxiety during all trimesters of pregnancy (Table 5). 


\begin{tabular}{|l|l|l|l|}
\hline Table 2. Environmental-social variables of the study group \\
\hline Variable & Value of the variable & $n$ & $\%$ \\
\hline \multirow{4}{*}{$\begin{array}{l}\text { Stress factors in } \\
\text { pregnancy }\end{array}$} & yes & 129 & 71.27 \\
\cline { 2 - 4 } & no & 52 & 28.73 \\
\hline Stress type & problems at work & 31 & 24.04 \\
\cline { 2 - 4 } & financial & 54 & 41.86 \\
\cline { 2 - 4 } & housing conditions & 22 & 17.05 \\
\cline { 2 - 4 } & death in the family & 8 & 6.2 \\
\cline { 2 - 4 } & others & 14 & 10.85 \\
\hline Housing conditions & very good & 73 & 40.33 \\
\cline { 2 - 4 } & good & 90 & 49.72 \\
\cline { 2 - 4 } & without comforts & 18 & 9.95 \\
\hline Family support & yes & 156 & 86.19 \\
\cline { 2 - 4 } & no & 25 & 13.81 \\
\hline \multirow{4}{*}{$\begin{array}{l}\text { Support of others } \\
\text { possible) }\end{array}$} & yes & 157 & 86.75 \\
\cline { 2 - 4 } & no & 24 & 13.25 \\
\cline { 2 - 4 } & acquaintances & 100 & 63.69 \\
\cline { 2 - 4 } & neighbors & 18 & 11.46 \\
\cline { 2 - 4 } & friends & 90 & 57.32 \\
\cline { 2 - 4 } & others & 5 & 3.18 \\
\hline \multirow{5}{*}{ Financial situation } & very good & 41 & 17.13 \\
\cline { 2 - 4 } & good & 22.65 \\
\cline { 2 - 4 } & insufficient & & 59.22 \\
\hline
\end{tabular}

$n$ - number of those researched.

\begin{tabular}{|c|c|c|c|c|c|c|c|c|}
\hline \multirow[t]{2}{*}{ Anxiety } & \multicolumn{2}{|c|}{$\begin{array}{l}\text { STAI X-2 } \\
\text { trait }\end{array}$} & \multicolumn{2}{|c|}{$\begin{array}{l}\text { STAI X-1 } \\
\text { state (I) }\end{array}$} & \multicolumn{2}{|c|}{$\begin{array}{l}\text { STAI X-1 } \\
\text { state (II) }\end{array}$} & \multicolumn{2}{|c|}{$\begin{array}{l}\text { STAI X-1 } \\
\text { state (III) }\end{array}$} \\
\hline & $n$ & $\%$ & $n$ & $\%$ & $n$ & $\%$ & $n$ & $\%$ \\
\hline High & 43 & 238 & 99 & 54.7 & 83 & \begin{tabular}{|l|}
46.4 \\
\end{tabular} & 108 & 59.7 \\
\hline Medium & 65 & 35.9 & 53 & 29.3 & 61 & \begin{tabular}{|l|l|}
34.1 \\
\end{tabular} & 52 & 2.7 \\
\hline Low & 73 & 40.3 & 29 & 16.0 & 35 & 19.5 & 21 & 11.6 \\
\hline
\end{tabular}

$n$ - number of those researched.

Table 4. Descriptive statistics of state anxiety (STAI X-1)
in particular trimesters of pregnancy
\begin{tabular}{|l|l|l|l|l|l|l|} 
Anxiety & SD & Me & $\begin{array}{l}\text { Min- } \\
- \text { max }\end{array}$ & $\mathbf{Q}_{1-} \mathbf{Q}_{3}$ & chi' $^{2}$ & $p$ \\
\hline $\begin{array}{l}\text { STAI X-1 } \\
\text { state (I) }\end{array}$ & $6.5 \pm 1.9$ & 7.0 & $3-10$ & $5-8$ & 30.35 & $<0.001$ \\
\cline { 1 - 5 } $\begin{array}{l}\text { STAI X-1 } \\
\text { state (II) }\end{array}$ & $6.2 \pm 1.9$ & 6.0 & $1-10$ & $5-8$ & & \\
\cline { 1 - 5 } $\begin{array}{l}\text { STAI X-1 } \\
\text { state (III) }\end{array}$ & $6.7 \pm 1.7$ & 7.0 & $3-10$ & $6-8$ & & \\
\hline
\end{tabular}

$\mathrm{SD}$ - mean and standard deviation; min - minimum value; max - maximum value; $\mathrm{Q}_{1}$ - lower quartile; $\mathrm{Q}_{3}$ - upper quartile; $\mathrm{Me}$ - median; Pearson's chi-square test; $p$ - level of significance set for the statistics.

\begin{tabular}{|c|c|c|c|c|}
\hline Parameters & $n$ & $R$ & $t(n-2)$ & $p$ \\
\hline $\begin{array}{l}\text { STAI X-2 trait \& STAI } \\
\text { X-1 state (I) }\end{array}$ & 181 & 0.706 & 13.34 & $<0.001$ \\
\hline $\begin{array}{l}\text { STAI X-2 trait \& STAI } \\
\text { X-1 state (II) }\end{array}$ & 181 & 0.640 & 11.09 & $<0.001$ \\
\hline $\begin{array}{l}\text { STAI X-2 trait \& STAI } \\
\text { X-1 state (III) }\end{array}$ & 181 & 0.61 & 10.38 & $<0.001$ \\
\hline
\end{tabular}

$R$-Spearman's rank correlation coefficient; $t(n-2)$ - stats test to check the significance of correlation coefficient $R ; p$ - level of significance set for the statistics; $n$ - number of those researched.

Data analysis showed statistically significant differences $(p<0.001)$ in the occurrence of trait anxiety in those pregnant concerning stress factors during pregnancy. In those women who experienced stress during pregnancy, trait anxiety levels were significantly higher $(p<0.001)$ in all three trimesters than in those who did not face stress factors (Table 6).

Statistically significant differences $(p<0.001)$ were observed in the occurrence of trait anxiety in pregnant women depending on the family support received. Women who could not count on support from family during pregnancy experienced state anxiety statistically significantly more often $(p<0.001)$ in all three trimesters of pregnancy. Analysis of the occurrence of trait anxiety and state anxiety with regard to support of family and other people is presented in Table 7.

\begin{tabular}{|c|c|c|c|c|c|c|c|c|}
\hline & & $n$ & SD & Min-Max & $Q_{1}-Q_{3}$ & Me & $z$ & $p$ \\
\hline \multicolumn{9}{|l|}{ Stress factors } \\
\hline \multirow[t]{2}{*}{ STAI X-2 trait } & yes & 129 & $5.6 \pm 1.9$ & $1-10$ & $4-7$ & 6.0 & \multirow[t]{2}{*}{5.13} & \multirow[t]{2}{*}{$<0.001$} \\
\hline & no & 52 & $4.1 \pm 1.9$ & $1-9$ & $3-5$ & 4.0 & & \\
\hline \multirow[t]{2}{*}{ STAI X-1 state (I) } & yes & 129 & $7.1 \pm 1.7$ & $3-10$ & $6-8$ & 7.0 & \multirow[t]{2}{*}{4.44} & \multirow[t]{2}{*}{$<0.001$} \\
\hline & no & 52 & $5.8 \pm 1.7$ & $3-9$ & $5-7$ & 6.0 & & \\
\hline \multirow[t]{2}{*}{ STAI X-1 state (II) } & yes & 129 & $5.8 \pm 1.8$ & $1-10$ & $6-8$ & 7.0 & \multirow[t]{2}{*}{4.96} & \multirow[t]{2}{*}{$<0.001$} \\
\hline & no & 52 & $5.4 \pm 1.7$ & $3-9$ & $4-6$ & 6.0 & & \\
\hline \multirow[t]{2}{*}{ STAI X-1 state (III) } & yes & 129 & $7.3 \pm 1.5$ & $3-10$ & $7-8$ & 8.0 & \multirow[t]{2}{*}{5.38} & \multirow[t]{2}{*}{$<0.001$} \\
\hline & no & 52 & $5.9 \pm 1.5$ & $3-10$ & $5-7$ & 6.0 & & \\
\hline
\end{tabular}

$\mathrm{SD}$ - mean and standard deviation; min - minimum value; max - maximum value; $\mathrm{Q}_{1}$ - lower quartile; $\mathrm{Q}_{3}$ - upper quartile; $\mathrm{ME}$ - median; $Z$ - $\mathrm{U}$ Mann-Whitney test; $p$ - level of significance set for statistics; $n$ - number of those researched. 


\begin{tabular}{|c|c|c|c|c|c|c|c|c|}
\hline & & $n$ & SD & Min-Max & $Q_{1}-Q_{3}$ & Me & $z$ & $p$ \\
\hline \multicolumn{9}{|l|}{ Family support } \\
\hline \multirow[t]{2}{*}{ STAI X-2 trait } & yes & 156 & $4.5 \pm 1.9$ & $1-9$ & $3-6$ & 5.0 & \multirow[t]{2}{*}{5.33} & \multirow[t]{2}{*}{$<0.001$} \\
\hline & no & 25 & $7.1 \pm 1.8$ & $3-10$ & $6-8$ & 7.0 & & \\
\hline \multirow[t]{2}{*}{ STAI X-1 state (I) } & yes & 156 & $6.2 \pm 1.7$ & $3-10$ & $5-7$ & 6.0 & \multirow[t]{2}{*}{5.31} & \multirow[t]{2}{*}{$<0.001$} \\
\hline & no & 25 & $8.3 \pm 1.4$ & $5-10$ & $8-9$ & 8.0 & & \\
\hline \multirow[t]{2}{*}{ STAI X-1 state (II) } & yes & 156 & $5.9 \pm 1.7$ & $1-10$ & $5-7$ & 6.0 & \multirow[t]{2}{*}{5.10} & \multirow[t]{2}{*}{$<0.001$} \\
\hline & no & 25 & $7.9 \pm 1.5$ & $3-10$ & $8-9$ & 8.0 & & \\
\hline \multirow[t]{2}{*}{ STAI X-1 state (III) } & yes & 156 & $6.4 \pm 1.6$ & $3-10$ & $5,5-8$ & 7.0 & \multirow[t]{2}{*}{4.52} & \multirow[t]{2}{*}{$<0.001$} \\
\hline & no & 25 & $8.2 \pm 1.5$ & $4-10$ & $8-10$ & 8.0 & & \\
\hline \multicolumn{9}{|c|}{ Support of other people } \\
\hline \multirow[t]{2}{*}{ STAI X-2 trait } & yes & 157 & $4.9 \pm 2.1$ & $1-10$ & $4-6$ & 5.0 & \multirow[t]{2}{*}{0.28} & \multirow[t]{2}{*}{$>0.05$} \\
\hline & no & 24 & $4.9 \pm 2.1$ & $1-9$ & $3-6.5$ & 5.0 & & \\
\hline \multirow[t]{2}{*}{ STAI X-1 state (I) } & yes & 157 & $6.5 \pm 1.8$ & $3-10$ & $6-8$ & 7.0 & \multirow[t]{2}{*}{0.13} & \multirow[t]{2}{*}{$>0.05$} \\
\hline & no & 24 & $6.4 \pm 2.1$ & $3-10$ & $5-8$ & 7.0 & & \\
\hline \multirow[t]{2}{*}{ STAI X-1 state (II) } & yes & 157 & $6.1 \pm 1.8$ & $1-10$ & $5-7.5$ & 6.0 & \multirow[t]{2}{*}{-0.70} & \multirow[t]{2}{*}{$>0.05$} \\
\hline & no & 24 & $6.4 \pm 2.0$ & $3-9$ & $5-8$ & 6.0 & & \\
\hline \multirow[t]{2}{*}{ STAI X-1 state (III) } & yes & 157 & $6.6 \pm 1.6$ & $3-10$ & $6-8$ & 7.0 & \multirow[t]{2}{*}{-0.92} & \multirow[t]{2}{*}{$>0.05$} \\
\hline & no & 24 & $6.9 \pm 2.0$ & $3-10$ & $5.5-8.5$ & 7.5 & & \\
\hline
\end{tabular}

$\mathrm{SD}$ - mean and standard deviation; min - minimum value; max - maximum value; $\mathrm{Q}_{1}$ - lower quartile; $\mathrm{Q}_{3}$ - upper quartile; $\mathrm{ME}$ - median; $Z$ - $U$ Mann-Whitney test; $p$ - level of significance set for statistics; $n$ - number of those researched.

In women who declared worse housing conditions, both trait and state anxiety levels were significantly higher $(p<0.001)$ in all three trimesters of pregnancy (Table 8 ). There are also statistically significant differences $(p<0.001)$ in the occurrence of trait anxiety in pregnant women with regard to their financial situation. Women suffering from financial difficulties had significantly higher levels of state anxiety $(p<0.001)$ during all trimesters of pregnancy.

\begin{tabular}{|c|c|c|c|c|c|c|c|c|}
\hline & & $n$ & SD & Min-Max & $Q_{1}-Q_{3}$ & Me & $H$ & $p$ \\
\hline \multicolumn{9}{|c|}{ Self-evaluation of housing conditions } \\
\hline \multirow[t]{3}{*}{ STAI X-2 trait } & very good & 73 & $4.5 \pm 2.0$ & $1-9$ & $3-6$ & 5.0 & \multirow[t]{3}{*}{10.66} & \multirow[t]{3}{*}{$<0.01$} \\
\hline & good & 90 & $4.9 \pm 1.9$ & $1-9$ & $4-6$ & 5.0 & & \\
\hline & without comforts & 18 & $6.3 \pm 2.6$ & $1-10$ & $5-8$ & 7.0 & & \\
\hline \multirow{3}{*}{ STAI X-1 state (I) } & very good & 73 & $6.2 \pm 1.7$ & $3-10$ & $5-7$ & 6.0 & \multirow[t]{3}{*}{13.04} & \multirow[t]{3}{*}{$<0.01$} \\
\hline & good & 90 & $6.4 \pm 1.8$ & $3-10$ & $5-8$ & 7.0 & & \\
\hline & without comforts & 18 & $7.9 \pm 1.8$ & $3-10$ & $7-9$ & 8.0 & & \\
\hline \multirow[t]{3}{*}{ STAI X-1 state (II) } & very good & 73 & $5.8 \pm 1.8$ & $1-9$ & $4-7$ & 6.0 & \multirow[t]{3}{*}{14.93} & \multirow[t]{3}{*}{$<0.001$} \\
\hline & good & 90 & $6.1 \pm 1.7$ & $3-10$ & $5-7$ & 6.0 & & \\
\hline & without comforts & 18 & $7.6 \pm 1.5$ & $3-9$ & $7-9$ & 8.0 & & \\
\hline \multirow[t]{3}{*}{ STAI X-1 state (III) } & very good & 73 & $6.2 \pm 1.6$ & $3-10$ & $5-7$ & 6.0 & \multirow[t]{3}{*}{20.48} & \multirow[t]{3}{*}{$<0.001$} \\
\hline & good & 90 & $6.8 \pm 1.6$ & $3-10$ & $6-8$ & 7.0 & & \\
\hline & without comforts & 18 & $8.0 \pm 1.6$ & $3-10$ & $8-9$ & 8.0 & & \\
\hline \multicolumn{9}{|c|}{ Self-evaluation of financial situation } \\
\hline \multirow[t]{3}{*}{ STAI X-2 trait } & very good & 31 & $3.8 \pm 2.2$ & $1-9$ & $2-6$ & 4.0 & \multirow[t]{3}{*}{23.87} & \multirow[t]{3}{*}{$<0.001$} \\
\hline & good & 109 & $4.7 \pm 1.8$ & $1-9$ & $4-6$ & 5.0 & & \\
\hline & insufficient & 41 & $6.1 \pm 1.9$ & $1-10$ & $5-7$ & 6.0 & & \\
\hline \multirow[t]{3}{*}{ STAI X-1 state (I) } & very good & 31 & $5.9 \pm 1.9$ & $3-9$ & $5-7$ & 6.0 & \multirow[t]{3}{*}{18.04} & \multirow[t]{3}{*}{$<0.001$} \\
\hline & good & 109 & $6.2 \pm 1.7$ & $3-10$ & $5-7$ & 6.0 & & \\
\hline & insufficient & 41 & $7.5 \pm 1.7$ & $3-10$ & $7-9$ & 8.0 & & \\
\hline \multirow[t]{3}{*}{ STAI X-1 state (II) } & very good & 31 & $5.3 \pm 2.0$ & $1-9$ & $3-7$ & 5.0 & \multirow[t]{3}{*}{20.01} & \multirow[t]{3}{*}{$<0.001$} \\
\hline & good & 109 & $6.0 \pm 1.7$ & $3-10$ & $5-7$ & 6.0 & & \\
\hline & insufficient & 41 & $7.2 \pm 1.5$ & $3-9$ & $6-8,5$ & 8.0 & & \\
\hline \multirow[t]{3}{*}{ STAI X-1 state (III) } & very good & 31 & $5.6 \pm 1.6$ & $3-9$ & $4-7$ & 6.0 & \multirow[t]{3}{*}{27.95} & \multirow[t]{3}{*}{$<0.001$} \\
\hline & good & 109 & $6.6 \pm 1.5$ & $3-10$ & $6-8$ & 7.0 & & \\
\hline & insufficient & 41 & $7.7 \pm 1.7$ & $3-10$ & $7-9$ & 8.0 & & \\
\hline
\end{tabular}

$\mathrm{SD}$ - mean and standard deviation; min - minimum value; max - maximum value; $\mathrm{Q}_{1}$ - lower quartile; $\mathrm{Q}_{3}-\mathrm{upper}$ quartile; $\mathrm{ME}$ - median; $\mathrm{H}$ - Kruskal-Wallis test; $p$ - level of significance set for statistics; $n$ - number of those researched; $\%$ - percent. 


\section{Discussion}

Mental health, including a pregnant woman's emotional state, does not remain irrelevant for the development of the fetus, the course of labor or a mother's adaptation during the postnatal period $[2,25,26]$. In women who showed high levels of stress and anxiety, we observed higher indicators of self-induced miscarriages, premature childbirths, developmental disorders of the fetus and postpartum psychosis [27-32]. This longitudinal analysis of original research concerning the occurrence of anxiety, conducted in the first, second and third trimester of pregnancy, allows for a broader understanding of the impact of environmental factors on pregnancy and a woman's mental state. The study on anxiety and depression in pregnant women revealed that the rate of occurrence of anxiety in particular pregnancy trimesters exceeded 30\% [33]. Studies indicate a varying severity of stress levels depending on the trimester of pregnancy. In the first trimester, high levels of anxiety occurred in $54.7 \%$ of the participants, in the second - in $46.37 \%$, while in the third one - in 59.67\% [33-36].

In this study, high levels of anxiety in the first trimester were noted in $21.6 \%$ of those researched, and in the second one - in $16.6 \%$ [33]. Studies on psychological aspects of pregnancy show that the intensity of anxiety is not similar through the entire pregnancy [24]. It has been proven that the intensity is relatively high during the first and the third trimesters, while it gets remarkably lower in the second trimester. It has been noted that pregnant women with high levels of trait anxiety were also characterized by a higher intensity of state anxiety in all trimesters of pregnancy. Stress factors should be identified before pregnancy to take interdisciplinary action and exclude harmful elements from the woman's and the family's environment. Differences were analyzed in the occurrence of anxiety in relation to the financial and housing situations declared by the respondents. Statistically significant differences in all trimesters of pregnancy were reported in the study, noting an increase of anxiety levels in groups worse off and those with worse housing conditions. Similar results were obtained by Morylowska-Topolska in a study among women who assessed both their financial and housing situation as average or bad, reaching the highest levels of anxiety according to HADS in all three trimesters [33]. However, those pregnant who assessed the above-mentioned situations as very good presented the lowest HADS results, which may suggest that subjective evaluation of both the financial and housing situation has a greater impact on the emergence of anxiety [33]. Studies by Giardinelli et al. also confirm that the higher the social-economic status, the lower the risk of the occurrence of anxiety and depression symptoms during pregnancy [37]. It was noted that the risk of pregnancy complications in a population of women may reach about $46 \%$, and in women who did not receive such support, it was as high as $91 \%$ [38]. Studies by many authors confirm that pregnant women lacking the support of their partner or other close individuals show high levels of prenatal anxiety and depression [39]. This original research on the type of given support revealed that women who declared they received help from the closest family were characterized with significantly lower levels of both trait and state anxiety in all trimesters of pregnancy than those who were deprived of such support. Apart from the support of family offered to pregnant women, the help of other people (neighbors, friends) might seem to be of importance. Thise original research, however, did not verify such differences. According to studies by Bowen and Muhajarine, social support best protected women against anxiety and depression in the third trimester of pregnancy, as well as against depression in the second and third trimester [40, 41]. In our study, we analyzed the impact of stress factors during pregnancy, such as problems at work, financial issues, poor living conditions and death in the family, related to anxiety levels in women. In the part of the group exposed to these factors, the "anxiety understood as current emotional state" level was approximately 5.67 sten, and this was significantly higher than in women who were not expose to unfavorable factors. The authors observed the same differences in the levels of "anxiety understood as a permanent personality trait" during every trimester of pregnancy. Wiktor et al. published similar results, and their study showed increased levels of "anxiety understood as current emotional state" in the group of women who experienced a death in the family recently, medium level of "anxiety understood as current emotional state" in these women was 7.12 sten points [42]. High anxiety levels during pregnancy and before childbirth are detrimental to both the pregnant woman's health and her child. Early diagnosis of determinants responsible for the emergence of anxiety in pregnancy, especially in high-risk group women, enables Primary Health Care $(\mathrm{PHC})$ professionals to take prophylactic or, more likely, therapeutic actions. A standard for the care of women is taking preventive care of all women, identifying risk factors and assessing the severity of anxiety and depression. A family midwife is obliged to take care of a pregnant woman and her family by monitoring pregnancy and fetal growth, as well as by providing health education. In the implementation of the health care services, the position of the midwife is to cooperate with the PHC doctor, gynecologist, PHC nurse and representatives of health organizations and institutions. Psycho-prophylactic actions must be directed at the needs of pregnant women who were individually diagnosed as being adversely influenced by their home and work environment.

\section{Limitations of the study}

A limitation of our study is the absence of an assessment of the severity of anxiety as a characteristic and condition up to 3 months after childbirth. This would allow for assessing what other factors related to the care of newborns and infants affect the sensation of anxiety, however, this was not the aim of our study. Our goal was to analyze and evaluate anxiety levels in particular trimesters of pregnancy with regard to selected environmental factors.

\section{Conclusions}

Lack of support of family resulted in experiencing very intense anxiety by the researched women in each trimester. Financial issues and housing situation, as well as stress factors, brought about an escalation of anxiety in pregnant women.

Source of funding: This work was funded by the authors' own resources.

Conflicts of interest: The authors declare no conflicts of interest.

\section{References}

1. Makara-Studzińska M, Iwanowicz-Palus G. Psychologia w położnictwie i ginekologii. Warszawa: Wydawnictwo Lekarskie PZWL; 2009: 154-197 (in Polish).

2. Lonstein JS. Regulation of anxiety during the postpartum period. Front Neuroendocrinol 2007; 28: 115-141.

3. Robertson E, Grace S, Wallington T, et al. Antenatal risk factors for postpartum depression: a synthesis of recent literature. Gen Hosp Psychiatry 2004; 26: 289-295. 
4. Milan S, Ickovics JR, Kershaw T, et al. Prevalence, course, and predictors of emotional distress in pregnant and parenting adolescents. J Consul Clin Psychol 2004; 72: 328-340.

5. Friedman SH, Heneghan A, Rosenthal M. Characteristics of women who deny or conceal a pregnancy. Psychosomatics 2007; 48: 117$-122$.

6. Sharp HM, Bramwell R. An empirical evaluation of a psychoanalytic theory of mothering orientation: implications for the antenatal prediction of postnatal depression. J Reprod and Infant Psychol 2004; 22: 71-89.

7. IP WY, Tang CS, Goggins WB. An educational intervention to improve women's ability to cope with childbirth. JCN 2009; 18: 2125-2135.

8. Morylowska-Topolska J, Makara-Studzińska M, Kotarski J. The influence of sociodemographic and medical variables on the severity of anxiety and depressive symptoms during particular trimesters of pregnancy. Psychiatr Pol 2014; 48(1): 173-186.

9. Gebuza G, Kaźmierczak M, Gierszewska M, et al. Lęk przed porodem w III trymestrze ciąży i jego powiązania ze stanem noworodka. MONZ 2015; 21(1): 39-44 (in Polish).

10. Cassidy-Bushrow AE, Peters RM, Johnson DA, et al. Association of depressive symptoms with inflammatory biomarkers among pregnant African-American women. J Reprod Immunol 2012; 94(2): 202-209.

11. Yau YH, Potenza MN. Stress and eating behaviors. Minerva Endocrinol 2013; 38(3): 255-267.

12. Szydełko J, Szydełko M, Piątek D, et al. Wpływ chronicznego stresu u kobiet w ciąży na kształtowanie się zachowań żywieniowych u ich potomstwa w życiu postnatalnym. Medical Review 2016; 14(1): 83-92, doi: 10.15584/medrev.2016.1.7 (in Polish).

13. Boersma GJ, Tamashiro K. Individual differences in the effects of prenatal stress exposure in rodents. Neurobiol Stress 2015; 1: 100-108.

14. Whisman MA, Davila J, Goodman SH. Relationship adjustment, depression, and anxiety during pregnancy and the postpartum period. JFP 2011; 25: 375-383.

15. Dayan J, Yoshida K. Psychological and pharmacological treatments of mood and anxiety disorders during pregnancy and postpartum. Review and synthesis. J Obstet Gynecol Reprod 2007; 36: 530-548.

16. Glover V. Antenatal stress and anxiety and child behavioural problems: links and mechanisms. In: Annual Conference Society for Reprod and Infant Psychol; 2004 Sep. 8-10; Sheffield; 2004.

17. Ross LE, McLean LM. Anxiety disorders during pregnancy and the postpartum period: a systematic review. J Clin Psychiatry 2006; 67: $1285-1298$.

18. Beck CT. Postpartum depression: a metasynthesis. Qual Health Res 2002; 12: 453-472.

19. Beck CT. Predictors of postpartum depression: an update. Nutr Res Revi 2001; 50: 275-285.

20. Figueiredo $B$, Conde $A$. Anxiety and depression symptoms in women and men from early pregnancy to 3-months postpartum: parity differences and effects. J Affect Disord 2011; 132: 146-157.

21. Yonkers KA, Smith MV, Gotman N, et al. Typical somatic symptoms of pregnancy and their impact on a diagnosis of the major depressive disorder. Gen Hosp Psychiatry 2009; 31: 327-333.

22. Ciesielski M, Michałek M, Szlapo E, et al. Typy osobowości a zaburzenia emocjonalne u kobiet z patologicznym przebiegiem ciąży. Wiad Lek 1994; 47(1-2): 25-30 (in Polish).

23. Nierop A, Wirtz PH, Bratsikas A, et al. Stress-buffering effects of psychosocial re-sources on physiological and psychological stress response in pregnant women. Biol Psychol 2008; 78: 261-268.

24. Fatoye FO, Adeyemi AB, Oladimeji BY. Emotional distress and its correlates among Nigerian women in late pregnancy. J Obstet Gynecol 2004; 24(5): 504-509.

25. Dayan J. Clinical approach and epidemiological aspects of mood and anxiety disorders during pregnancy and postpartum. Review and synthesis. J Obstet Gynecol and Reprod Biol 2007; 36: 549-561.

26. Rutkowska A, Rolińska A, Kwaśniewski W, et al. Lęk - jako stan i jako cecha u kobiet w ciąży prawidłowej i wysokiego ryzyka. Curr Probl Psychiatry 2011; 12(1): 56-59 (in Polish).

27. Alder J, Fink N, Bitzer J, et al. Depression and anxiety during pregnancy: a risk factor for obstetric, fetal and neonatal outcome. A critical review of the literature. J Mater-Fetal Neonatal 2007; 20(3): 189-209, doi: 10.1080/14767050701209560.

28. Curzik DC, Jokic-Begic N. Anxiety sensitivity and anxiety as correlates of expected, experienced and recalled labor pain. J Psychosom Obstet Gynecol 2011; 32(4): 198-203.

29. Martini J, Knappe S, Beesdo-Baum K, et al. Anxiety disorders before birth and self-perceived distress during pregnancy: associations with maternal depression and obstetric, neonatal and early childhood outcomes. Early Hum Dev 2010; 86: 305-310.

30. Melka-Roszczyk M, Malinowski W. Psychoza poporodowa. Fam Med Prim Care Rev 2013; 15(3): 349-350 (in Polish).

31. Rubertsson C, Wickberg B, Gustavsson P, et al. Depressive symptoms in early pregnancy, two months and one-year postpartum-prevalence and psychosocial risk factors in a national Swedish sample. J Womens Health 2005; 8: 97-104.

32. Silva RA, Jansen K, Souza LD, et al. Depression during pregnancy in the Brazilian public health care system. Revi Bras Psiquiatr 2010; 32: 139-144.

33. Morylowska-Topolska J. Występowanie i czynniki ryzyka objawów lęku i depresji w okresie ciq̨ży (Dissertation). Lublin: Uniwersytet Medyczny; 2012 (in Polish).

34. Andersson L, Sundstrom-Poromaa I, Bixo M, et al. Point prevalence of psychiatric disorders during the second trimester of pregnancy: a population-based study. AJOG 2003; 189: 148-154.

35. Borri C, Mauri M, Oppo A, et al. Axis I psychopathology and functional impairment at the third month of pregnancy: results from the Perinatal Depression-Research and Screening Unit (PND-ReScU) study. J Clin Psychiatry 2008; 69: 1617-1624.

36. Grant KA, McMahon C, Austin MP. Maternal anxiety during the transition to parenthood: a prospective study. J Affect Disord 2008; 108: 101-111.

37. Giardinelli L, Innocenti A, Benni L, et al. Depression and anxiety in the perinatal period: prevalence and risk factors in an Italian sample. J Womens Health 2012; 15(1): 21-30.

38. Vrekoussis T, Kalantaridou SN, Mastorakos G, et al. The role of stress in female reproduction and pregnancy: an update. Ann N Y Acad Sci 2010; 1205: 69-75.

39. Reid H, Power M, Cheshire K. Factors influencing antenatal depression, anxiety and stress. Br J Midwifery 2009; 17: 501-508.

40. Bowen A, Muhajarine N. Antenatal depression. Can J Nursing 2006; 102: 27-30.

41. Littleton $\mathrm{HL}$, Breitkopf $\mathrm{CR}$, Berenson $\mathrm{AB}$. Correlates of anxiety symptoms during pregnancy and association with perinatal outcomes: a meta-analysis. Am J Obstet Gynecol 2007; 196: 424-432.

42. Wiktor H, Lewicka M, Humeniuk E. et al. Ocena poziomu lęku u kobiet w połogu. Ann Acad Med Stetin 2009; 55(1): 66-69 (in Polish).

Tables: 8

Figures: 0

References: 42 
Received: 20.02 .2018

Reviewed: 23.03.2018

Accepted: 06.06.2018

Address for correspondence:

Dorota Branecka-Woźniak, MA, PhD

Katedra i Zakład Ginekologii i Zdrowia Prokreacyjnego PUM

ul. Żołnierska 48

71-210 Szczecin

Polska

Tel.: +48 91 48-00-920

E-mail: dobrawo@gmail.com 